\title{
ZnO Nanoparticles on Si, Si/Au, and Si/Au/ZnO Substrates by Mist-Atomisation
}

\author{
Z. Khusaimi, ${ }^{1,2}$ M. H. Mamat, ${ }^{3}$ N. Abdullah, ${ }^{4}$ and M. Rusop ${ }^{1,3}$ \\ ${ }^{1}$ NANO-SciTech Centre (NST), Institute of Science, Universiti Teknologi MARA (UiTM), 40450 Shah Alam, Selangor, Malaysia \\ ${ }^{2}$ Faculty of Applied Sciences, Universiti Teknologi MARA (UiTM), 40450 Shah Alam, Selangor, Malaysia \\ ${ }^{3}$ NANO-Electronic Centre (NET), Faculty of Electrical Engineering, Universiti Teknologi MARA (UiTM), 40450 Shah Alam, \\ Selangor, Selangor 40450 Shah Alam, Malaysia \\ ${ }^{4}$ Faculty of Science, Universiti Malaya, 55000 Kuala Lumpur, Malaysia
}

Correspondence should be addressed to Z. Khusaimi, zuraidakhusaimi@gmail.com

Received 11 April 2011; Revised 7 July 2011; Accepted 10 July 2011

Academic Editor: Parvaneh Sangpour

Copyright (c) 2012 Z. Khusaimi et al. This is an open access article distributed under the Creative Commons Attribution License, which permits unrestricted use, distribution, and reproduction in any medium, provided the original work is properly cited.

\begin{abstract}
$\mathrm{ZnO}$ nanoparticles were prepared on Si substrates by a mist-atomisation technique. Precursor of aqueous solution zinc nitrate and HMTA were released on substrates heated at 200,300 , and $400^{\circ} \mathrm{C}$ confined in chamber box. The surface of Si substrate was varied, that is, gold-seeded $\mathrm{Si}(\mathrm{Si} / \mathrm{Au}), \mathrm{ZnO}$ nanorods on $\mathrm{Si} / \mathrm{Au}(\mathrm{Si} / \mathrm{Au} / \mathrm{ZnO})$, and just $\mathrm{Si}$. The samples were subsequently analysed by X-ray diffraction, scanning electron microscopy, and photoluminescence (PL) spectroscopy to study their structural, surface morphology, and PL emission properties. Analysis from the XRD patterns of the films showed strong $a$-and $c$-axis lattice and of pure $\mathrm{ZnO}$ hexagonal wurtzite type. The crystallite size varied from 6 to $43 \mathrm{~nm}$ and was found to generally increase with increasing substrates' temperatures $\left(T_{s}\right)$. SEM micrographs revealed granular-like structure throughout. Shifts pattern of PL emission at ultraviolet and visible range was found to support size changes observed. Both substrate surface type and deposition temperature were found to significantly affect crystalline growth of $\mathrm{ZnO}$ nanoparticles. Chemical equations and justification for growth patterns are also suggested.
\end{abstract}

\section{Introduction}

Zinc oxide $(\mathrm{ZnO})$ is a very versatile material with a wide variety of usage (due to its properties such as white appearance, nontoxicity, antibacterial, polarity, and high thermal conductivity). $\mathrm{ZnO}$ is a thermally stable semiconducting metal oxide with wide energy band gap of $3.37 \mathrm{eV}$. In the field of electronics, some of its optoelectronic usages are as sensor, laser diode, light emitting diode (LED), and dye-synthesised solar cells. Nanostructured $\mathrm{ZnO}$ has been found to form various kinds of growth morphologies, like nanorods, nanowire, nanobelts, nanoflower, and tetrapods [1-3]. Synthesis of $\mathrm{ZnO}$ are carried out by many methods like chemical vapour deposition (CVD) $[4,5]$, pulsed laser deposition (PLD) $[6,7]$, magnetron sputtering [8], microwave irradiation $[9,10]$, hydrothermal $[11]$, sol-gel [12], solution method [13] and also spray pyrolysis [14]. Mist-atomisation is a process similarly known as spray pyrolysis. It is a physicochemical synthesis method used by advanced material researchers to produce thin film metal oxide nanostructures. Not restricted to metal oxides, this method may be used for production of simple oxides, binary, ternary oxides and superconducting oxides [15]. The process involves spraying precursor solution onto heated surface and the constituents react to form the intended products [16]. In this investigation, $\mathrm{ZnO}$ nanoparticles have been successfully grown by mist-atomisation deposition technique on Si substrate.

It was stipulated that besides concentration of precursor solution, deposition time and gas flow rate, temperature of the substrate significantly affects the final morphology and thickness of $\mathrm{ZnO}$ nanoparticles [15, 17]. A good quality nanostructured thin film is attainable by the formation of mist with small droplets and uniform distribution. In this investigation, by keeping the spraying rate constant, the temperature of substrate was varied at 200,300 , and $400^{\circ} \mathrm{C}$ 


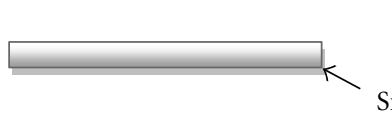

Bare Si substrate

(Si)

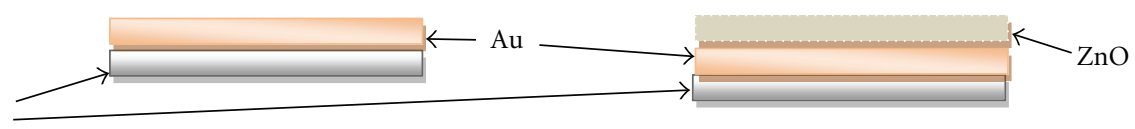

Gold-seeded Si substrate

$(\mathrm{Si} / \mathrm{Au})$
$\mathrm{ZnO}$ nanorods on gold-seeded $\mathrm{Si}$

Substrate $(\mathrm{Si} / \mathrm{Au} / \mathrm{ZnO})$

Figure 1: Type of surfaces used to deposit $\mathrm{ZnO}$ nanostructured thin films by mist-atomisation.

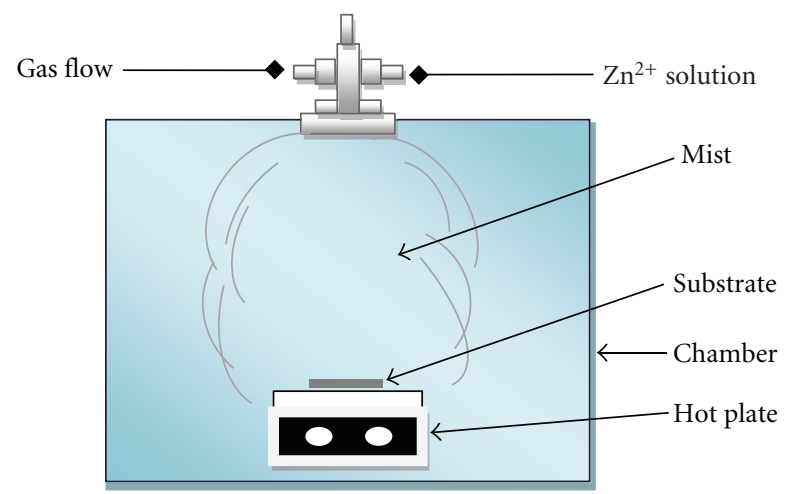

FIgURE 2: Schematic diagram of a mist-atomisation technique.

and deposited on Si substrate. It was also investigated if $\mathrm{ZnO}$ formed by mist-atomiser is sensitive to the type of surface of Si substrate, that is, bare polished $\mathrm{Si}(\mathrm{Si})$, gold-seeded $\mathrm{Si}$ substrate $(\mathrm{Si} / \mathrm{Au})$, and $\mathrm{ZnO}$ nanorods grown by immersion sol-gel method on gold-seeded $\mathrm{Si}$ substrate $(\mathrm{Si} / \mathrm{Au} / \mathrm{ZnO})$ (Figure 1).

\section{Experimental}

$\mathrm{ZnO}$ nanoparticles were obtained by a mist-atomisation technique in air atmosphere. This cost-effective method is suitable to deposit large area of substrates with metal-oxide nanostructures at low temperature. The setup consisted of three components, that is, a steel pneumatic atomiser, hot-plate deposition surface, and our own designed acrylic chamber, $50 \times 50 \times 50 \mathrm{~cm}^{3}$ (Figure 2). The distance of the atomiser to hot-plate surface is thus fixed at $39.5 \mathrm{~cm}$. Temperature inside the chamber was measured using IR thermometer Brand Fluke 62 Mini IR and was detected to be approximately $30^{\circ} \mathrm{C}$ less than temperature of regulated substrate surface. The initial solution is zinc nitrate hexahydrate $\left(\mathrm{Zn}\left(\mathrm{NO}_{3}\right)_{2} \cdot 6 \mathrm{H}_{2} \mathrm{O}\right.$ dissolved in deionised (DI) water and mixed with aqueous solution of hexamethlyenetetramine $\left(\mathrm{C}_{6} \mathrm{H}_{12} \mathrm{~N}_{4}\right)$ (HMTA) at $0.05 \mathrm{M}$ concentration at $1: 1$ ratio. The precursor solution was released under high pressure through a tiny orifice with aspiration of atomic magnitude and subsequently contained as mists at ambient before it landed on the chosen substrates forming nanostructures of product. The growth was performed with a spray rate of $10 \mathrm{~mL} / \mathrm{min}$ on three different types of Si substrate surfaces at three different hot-plate temperatures of $\left(T_{s}\right)$ 200, 300, and $400^{\circ} \mathrm{C}$ with an accuracy of $\pm 5^{\circ} \mathrm{C}$. The first surface is bare silicon $(\mathrm{Si})$, the second surface is $6 \mathrm{~nm}$ of gold layer on $\mathrm{Si}$ substrate $(\mathrm{Si} / \mathrm{Au})$, and the third surface is $1 \mathrm{um} \mathrm{ZnO}$ nanorods on $\mathrm{Si} / \mathrm{Au}(\mathrm{Si} / \mathrm{Au} / \mathrm{ZnO})$ (Figure 1). The preparation techniques for the substrates have been explained elsewhere [18]. The obtained films were dried and annealed at $600^{\circ} \mathrm{C}$ for 1 hour and showed good adhesion to the substrate surface.

Structural characterisation was carried out by X-ray diffraction (XRD) using Rigaku RINT 2200/Ultima IV, $\mathrm{Cu} \mathrm{K} \alpha$ radiation over the range $2 \theta=30-40^{\circ}$ at room temperature. The surface morphology was investigated using JEOL JSM-636 OLA scanning electron microscope (SEM). Photoluminescence (PL) measurement was performed on PL-Raman (Horiba Jobin Yvon) at room temperature using a He-Cd lamp with excitation wavelength $325 \mathrm{~nm}$.

\section{Result and Discussion}

This simple method was carried out at ambient without the need of a vacuum rendering it suitable for large-scale industrial applications [19].

3.1. XRD. The XRD spectra on different substrate temperatures were presented in Figure 3. The results obtained were line-indexed with $\mathrm{ZnO}$ powder sample reported in JCPDS card no. 36-1451. All spectra showed strong prominent crystal diffraction planes of (100), (002), and (101) except for weak diffractions shown on $\mathrm{Si} / \mathrm{Au}$ substrate at $T_{s}=400^{\circ} \mathrm{C}$. The observed diffractions are similar to those found in bulk $\mathrm{ZnO}$.

$\mathrm{ZnO}$ prepared on $\mathrm{Si}$ (Figure $3(\mathrm{a})$ ) at $400^{\circ} \mathrm{C}$ exhibited high domination of (002) lattice orientation showing preference of c-axis orientation. This occurrence has been established to be due to lowest surface energy according to Wulff's theorem [20]. The theory stated that the equilibrium of crystal formation was to achieve minimum total surface energy for a given volume. Lowest surface energies are represented by the largest crystal surfaces and interplanar distances.

The XRD spectra of $\mathrm{ZnO}$ on $\mathrm{Si} / \mathrm{Au}$ (Figure 3(b)) exhibited extra lattice peaks belonging to gold ( $\mathrm{Au}$ ) peaks which are also noticeable at 33.096 and $38.215^{\circ}$. At $400^{\circ} \mathrm{C}$, the intensity of lattice peaks of $\mathrm{ZnO}$ was completely reduced. The eutectic point of $\mathrm{Au}$ with $\mathrm{Si}$ substrates is $363^{\circ} \mathrm{C}$ [21]. Therefore, at this higher temperature of $400^{\circ} \mathrm{C}$, the two solid of $\mathrm{Au}$ and $\mathrm{Si}$ coexist and may have caused the anomaly in the XRD pattern. This may also caused violent movements of $\mathrm{Zn}$ and $\mathrm{O}$ atoms led to improper growth of $\mathrm{ZnO}$. However, the lattice ratio c/a remained the same of 1.601 at 200 and $400^{\circ} \mathrm{C}$, and 1.602 at $300^{\circ} \mathrm{C}$. 

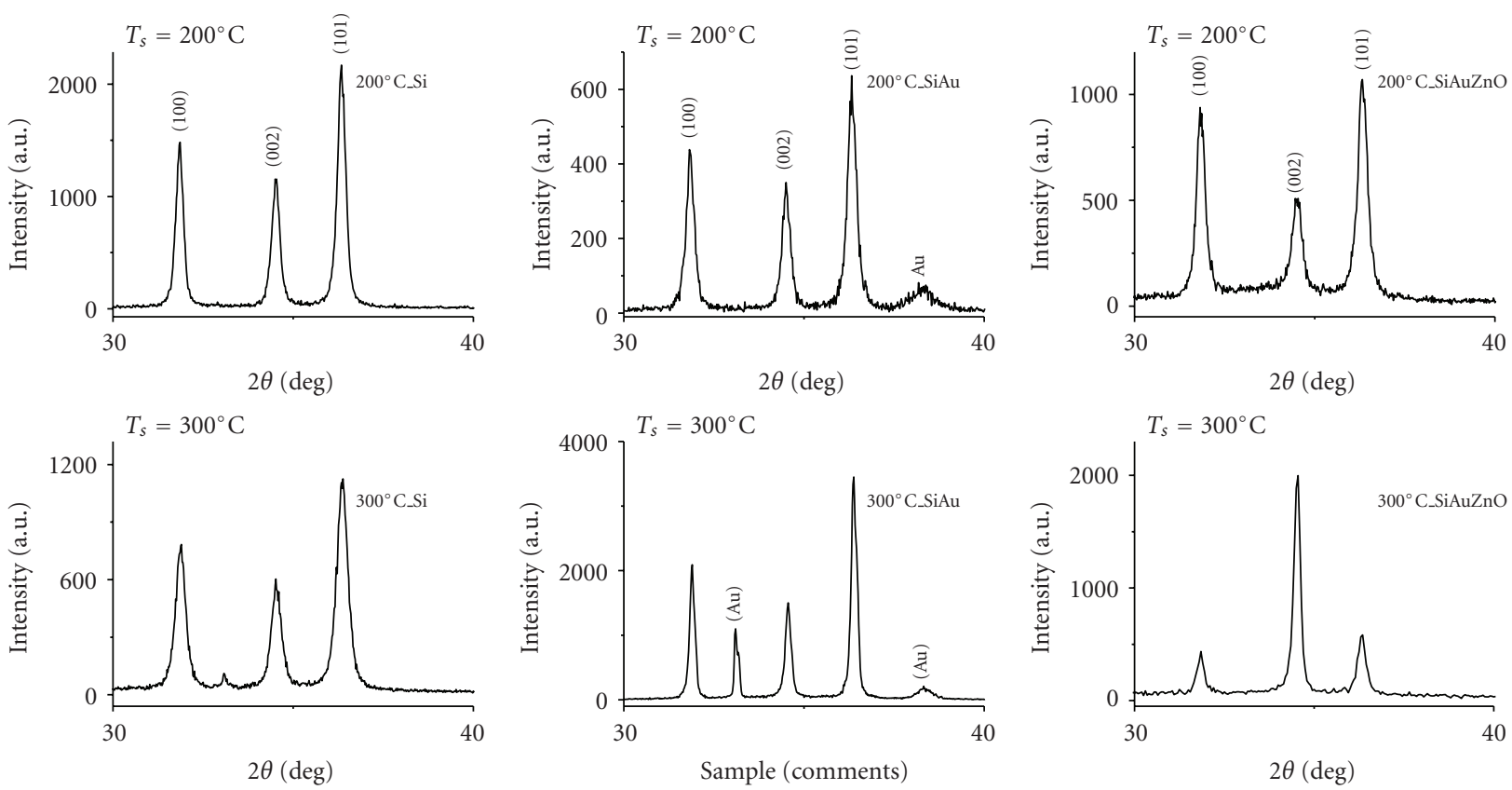

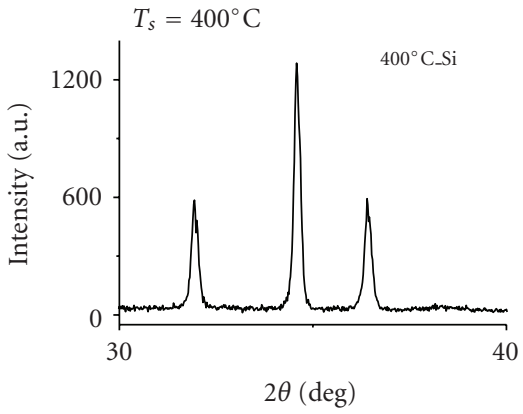

(a)

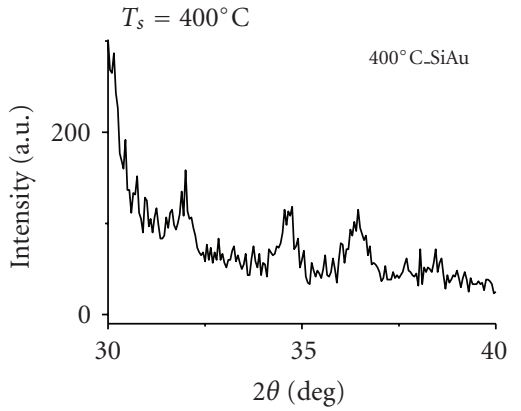

(b)

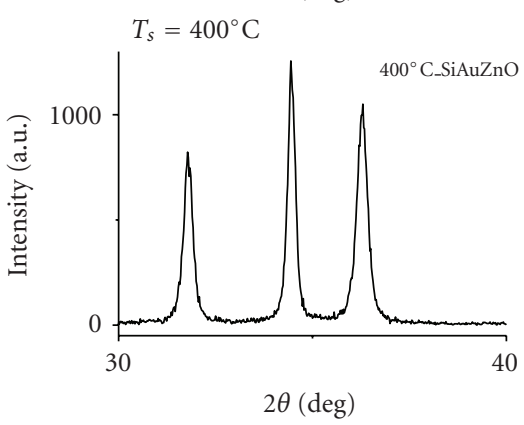

(c)

Figure 3: XRD data of $\mathrm{ZnO}$ nanoparticles deposited by mist-atomisation technique on (a) bare $\mathrm{Si}$ (b) gold-seeded $\mathrm{Si}(\mathrm{Si} / \mathrm{Au}$ ) and (c) $\mathrm{ZnO}$ nanorods on gold-seeded $\mathrm{Si}$ substrate $(\mathrm{Si} / \mathrm{Au} / \mathrm{ZnO})$, at substrate temperatures of 200,300 , and $400^{\circ} \mathrm{C}$.

XRD pattern of $\mathrm{ZnO}$ grown on $\mathrm{Si} / \mathrm{Au} / \mathrm{ZnO}$ (Figure 3(c)) at $T_{s}=300^{\circ} \mathrm{C}$ revealed prominent (002) lattice which appear to provide the optimum substrate temperature to grow vertically aligned $\mathrm{ZnO}$ possibly. The combination of this temperature and types of surface has definitely favoured the movement and placement of $\mathrm{Zn}$ and $\mathrm{O}$ atoms into proper site.

Lattice constants $a, c$, lattice ratios $c / a$, crystallite size, and $\%$ strain obtained from the XRD data of all the samples are presented in Table 1. Crystallite sizes were calculated by Williamson-Hall method. The lattice values are found to be very close to hexagonal $\mathrm{ZnO}$ powder sample standard values of $a=0.3249 \mathrm{~nm}$ and $c=0.5205 \mathrm{~nm}$ [22], indicating that the material prepared is pure $\mathrm{ZnO}$ hexagonal wurtzite type structure. Crystallite size and \% strain of all the prepared samples obtained from the analysis of XRD data [23], plotted as a function of temperature as shown in Figures 4(a) and 4(b).

Earlier works has shown that lattice parameters are temperature dependent. Expansion of lattice and particle size are in accordance with increase in temperature [24]. In this work we found that crystallite size of $\mathrm{ZnO}$ nanoparticles increased as $T_{s}$ increased for sample deposited on Si and $\mathrm{Si} / \mathrm{Au}$. Increment of particles size with increasing temperature of substrate has also been reported by other literature for semiconducting material by spray-pyrolysis methods $[25,26]$. The increase in size may be caused by integration of smaller particles into larger particles as indicated by Ostwald's ripening, which resulted to be due to potential energy difference among large and small particles via solid state diffusion.

However, the crystallite size showed shrinkage at higher $T_{s}$ of $400^{\circ} \mathrm{C}$ on $\mathrm{Si} / \mathrm{Au} / \mathrm{ZnO}$ substrate. The predeposited $\mathrm{ZnO}$ layer may have acted as an insulation layer resulting in similar effect to the thermal decomposition of the precursor droplets as it approaches the surface of substrates as those of lower $T_{s}$.

Upon calculation of $\%$ strain between $\mathrm{ZnO}$ nanoparticles to the substrate (Figure 4(b)), $\mathrm{ZnO}$ on $\mathrm{Si} / \mathrm{Au}$ substrate matched excellently as it was strain-free and simultaneously produced the smallest crystallite size. The predeposited $\mathrm{ZnO}$ layers were made up of $\mathrm{ZnO}$ nanorods with (002) lattice orientation. Lattice matching is another factor for superior 


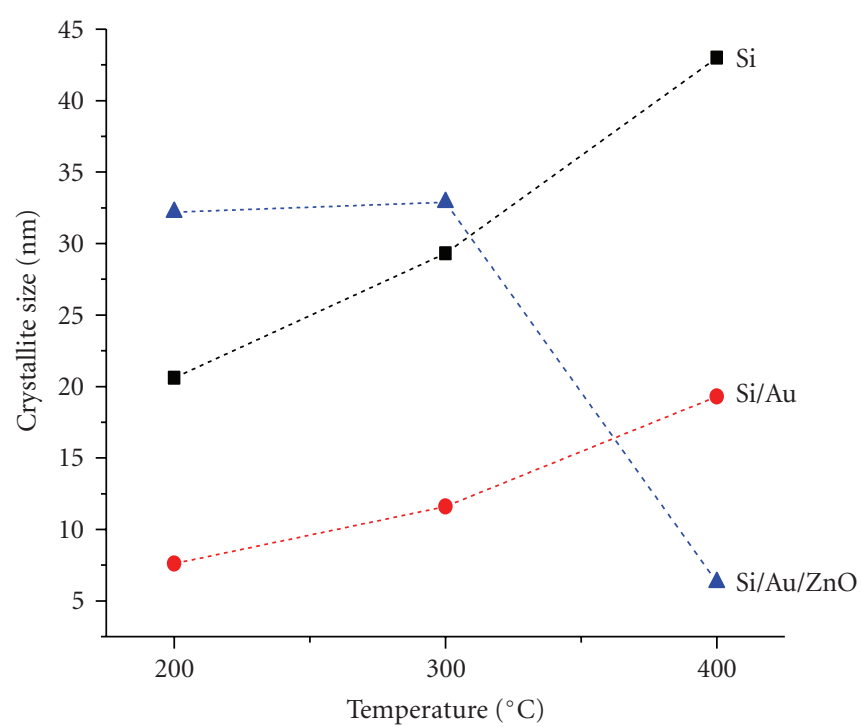

(a)

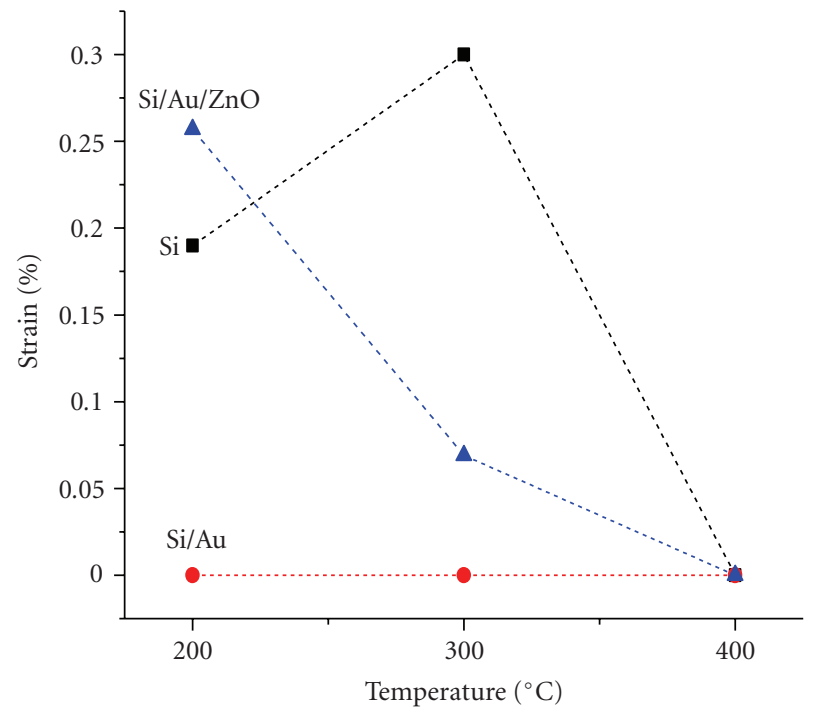

(b)

FIGURE 4: (a) Crystallite size, (b) \% strain of $\mathrm{ZnO}$ on three types of Si surface plotted as a function of substrate temperature.

growth of $\mathrm{ZnO}$ on substrates. A study carried out by $\mathrm{Li}$ et al. [27] comparing growth of $\mathrm{ZnO}$ on $\mathrm{Si}$ (111) and (100) has shown that $\mathrm{ZnO}$ grown on $\mathrm{Si}$ (111) exhibited greater growth density of $\mathrm{ZnO}$ nanorods compared to on $\mathrm{Si}$ (100). Thus predeposited $\mathrm{ZnO}$ film with other lattice orientation should also be considered for further studies.

This result suggests that the assumption of compatibility is not limited to type of material but rather also on the crystal orientation of the material, and thus needs further investigations.

From the result, deposition of $\mathrm{Zn}^{2+}$ solution by mistatomisation technique has proven to be capable of producing nanosized crystals of $\mathrm{ZnO}$. Thermogravimetric analysis (TGA) of the precursor solution showed that it degraded at $160^{\circ} \mathrm{C}$ [18], thus at the chosen substrate temperature of $200^{\circ} \mathrm{C}$ and above, the precursor would have been dissociated as it reaches the surface of substrates [17]. (Temperature inside chamber has been described at experimental.) Optimum deposition condition may have been achieved since the solvent was completely removed just before the droplet reaches the substrate [15]. The surfaces of the substrates were of dissimilar temperatures therefore the chemical reaction may have taken place either prior to, throughout, or subsequent to the mists of precursors reach the surface of the substrate.

The chemical reaction that took place is as suggested in the equations below

$$
\begin{aligned}
& \mathrm{Zn}\left(\mathrm{NO}_{3}\right)_{2} \cdot 6 \mathrm{H}_{2} \mathrm{O}_{(\mathrm{aq})}+\mathrm{C}_{6} \mathrm{H}_{12} \mathrm{~N}_{4(\mathrm{aq})} \\
& \quad \longrightarrow \mathrm{Zn}\left(\mathrm{C}_{6} \mathrm{H}_{12} \mathrm{~N}_{4}\right)(\mathrm{OH})_{2(\mathrm{aq})}+4 \mathrm{H}_{2} \mathrm{O}(\mathrm{g})+2 \mathrm{HNO}_{3(\mathrm{aq})}
\end{aligned}
$$

$$
\mathrm{Zn}\left(\mathrm{C}_{6} \mathrm{H}_{12} \mathrm{~N}_{4}\right)(\mathrm{OH})_{2(\mathrm{aq})} \longrightarrow \mathrm{Zn}(\mathrm{OH})_{2(\mathrm{~s})}+\mathrm{C}_{6} \mathrm{H}_{12} \mathrm{~N}_{4(\mathrm{~g})}
$$

$$
\mathrm{Zn}(\mathrm{OH})_{2(\mathrm{~s})} \longrightarrow \mathrm{ZnO}_{(\mathrm{s})}+\mathrm{H}_{2} \mathrm{O}_{(\mathrm{g})}
$$

It is suggested that zinc nitrate hexahydrate combined with HMTA molecule and formed a hydroxide complex (1). HMTA is an amine molecule which helped to chelate the $\mathrm{Zn}^{2+}$ ion [18] (2) and adsorbed on the sample and helped to determine growth morphology and irrelevant to the transition process [28]. The complex then dissociated into solid $\mathrm{Zn}(\mathrm{OH})_{2}$ while HMTA vapourised. Upon heating, $\mathrm{Zn}(\mathrm{OH})_{2}$ transform into $\mathrm{ZnO}$ and excess $\mathrm{H}_{2} \mathrm{O}$ removed (3).

3.2. SEM. The surface morphology of deposited nanostructured $\mathrm{ZnO}$ was captured by SEM. The mist-atomiser deposition of $\mathrm{ZnO}$ produced nanogranular structure in the range of $50-120 \mathrm{~nm}$ in most samples. The granules are rounded grains which interconnect if remain heated.

Figure 5(a) (i)-(iii) show the SEM micrographs of $\mathrm{ZnO}$ deposited on Si at 200,300 , and $400^{\circ} \mathrm{C}$. Thermal oxidation of Si substrate has been reported to occur at temperature higher than $400^{\circ} \mathrm{C}$, for example, from $800^{\circ} \mathrm{C}$ thus the substrate surface may be safely assumed to remain inert at the selected substrate temperatures $[29,30]$. It is clearly seen that with increasing substrates' temperature there is a tendency for the granules to interconnect as higher energy allows the grain boundary to expand and thus blend with other granules and form bigger grains. The interconnecting granules $(50-120 \mathrm{~nm})$ are also observed on samples deposited on $\mathrm{Si} / \mathrm{Au}$. This is thought to be due to the better efficiency of gold in conducting heat, having thermal conductivity of $\sim 310 \mathrm{~W} / \mathrm{mK}$ [31] relative to $\mathrm{Si}$ which is less than $200 \mathrm{~W} / \mathrm{mK}$ [32]. For the same reason, $\mathrm{ZnO}$ deposited on $\mathrm{Si} / \mathrm{Au}$ (Figure $5(\mathrm{~b})$ ) at $400^{\circ} \mathrm{C}$ showed bigger clusters of grains at $\sim 200 \mathrm{~nm}$ with greater disbanded granular boundaries.

The predeposited $\mathrm{ZnO}$ layer may have acted as an insulation layer resulting in similar effect to the thermal 
TABLE 1: Characteristics of $\mathrm{ZnO}$ nanostructured thin film from XRD analysis, grown on different Si substrate.

\begin{tabular}{|c|c|c|c|c|c|c|}
\hline Type of surface & Bare & $\mathrm{Si}(\mathrm{Si})$ & Gold-seeded S & $\mathrm{i}(\mathrm{Si} / \mathrm{Au})$ & $\mathrm{ZnO}$ nanorods or & ded $\mathrm{Si}(\mathrm{Si} / \mathrm{Au} / \mathrm{ZnO})$ \\
\hline $\begin{array}{l}\text { Substrate } \\
\text { temperature } \\
\left({ }^{\circ} \mathrm{C}\right)\end{array}$ & $\begin{array}{l}\text { Lattice constant } \\
(\AA) \text { and } c / a \text { ratio }\end{array}$ & $\begin{array}{l}\text { Crystallite size } \\
(\mathrm{nm}) \text { and \% } \\
\text { strain }\end{array}$ & $\begin{array}{l}\text { Lattice constant } \\
(\AA) \text { and } c / a \text { ratio }\end{array}$ & $\begin{array}{l}\text { Crystallite size } \\
(\mathrm{nm}) \text { and \% } \\
\text { strain }\end{array}$ & $\begin{array}{l}\text { Lattice constant } \\
(\AA) \text { and } c / a \text { ratio }\end{array}$ & $\begin{array}{l}\text { Crystallite size } \\
(\mathrm{nm}) \text { and \% strain }\end{array}$ \\
\hline 200 & $\begin{array}{l}a=3.244 \\
c=5.199 \\
c / a=1.603\end{array}$ & $\begin{array}{l}20.6 \\
0.109\end{array}$ & $\begin{array}{l}a=3.246 \\
c=5.196 \\
c / a=1.601\end{array}$ & $\begin{array}{l}7.6 \\
0\end{array}$ & $\begin{array}{l}a=3.246 \\
c=5.103 \\
c / a=1.572\end{array}$ & $\begin{array}{l}32.2 \\
0.257\end{array}$ \\
\hline 300 & $\begin{array}{l}a=3.242 \\
c=5.196 \\
c / a=1.603\end{array}$ & $\begin{array}{l}29.3 \\
0.300\end{array}$ & $\begin{array}{l}a=3.243 \\
c=5.195 \\
c / a=1.602\end{array}$ & $\begin{array}{l}11.6 \\
0\end{array}$ & $\begin{array}{l}a=3.246 \\
c=5.193 \\
c / a=1.600\end{array}$ & $\begin{array}{l}32.9 \\
0.069\end{array}$ \\
\hline 400 & $\begin{array}{l}a=3.245 \\
c=5.202 \\
c / a=1.603\end{array}$ & $\begin{array}{l}43.0 \\
0\end{array}$ & $\begin{array}{l}a=3.444 \\
c=5.517 \\
c / a=1.601\end{array}$ & $\begin{array}{l}19.3 \\
0\end{array}$ & $\begin{array}{l}a=3.247 \\
c=5.202 \\
c / a=1.602\end{array}$ & $\begin{array}{l}6.34 \\
0\end{array}$ \\
\hline
\end{tabular}
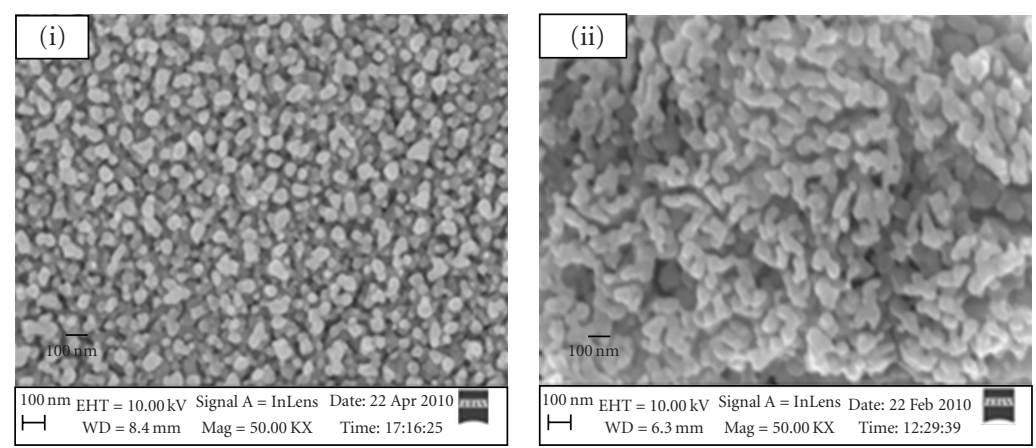

(a)

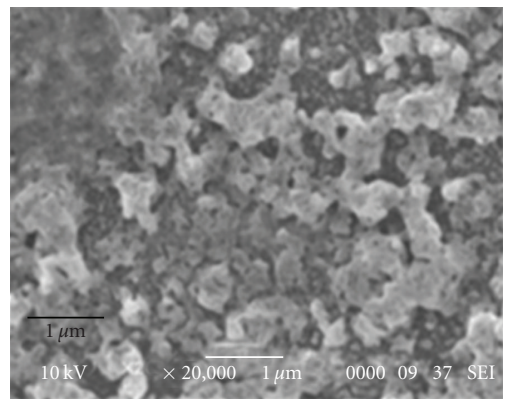

(b)

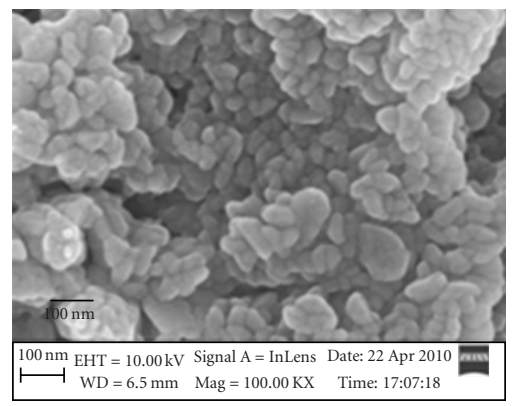

(c)

FIGURE 5: SEM micrographs ZnO nanoparticles deposited by mist-atomisation technique on (a) Si at substrate temperatures ( $T_{s}$ ) of (i) 200, (ii) 300 , (iii) $400^{\circ} \mathrm{C}$, (b) $\mathrm{Si} / \mathrm{Au}$ substrate at $T_{s}=400^{\circ} \mathrm{C}$ and (c) $\mathrm{Si} / \mathrm{Au} / \mathrm{ZnO}$ at $T_{s}=400^{\circ} \mathrm{C}$.

decomposition of the precursor droplets as it approaches the surface of substrates as those of lower $T_{s}$.

The effect of heat to $\mathrm{ZnO}$ nanoparticles on $\mathrm{Si} / \mathrm{Au} / \mathrm{ZnO}$ was different compared to those on $\mathrm{Si}$ and $\mathrm{Si} / \mathrm{Au}$ substrates. Heating at $400^{\circ} \mathrm{C}$ has not caused the expansion of the grain boundaries for the reason that $\mathrm{ZnO}$ has thermal conductivity value of less than $2 \mathrm{~W} / \mathrm{mK}$ [33], therefore the effect of $400^{\circ} \mathrm{C}$ was not as intense as it was on $\mathrm{Si}$ or $\mathrm{Si} / \mathrm{Au}$ substrates. Heat transport phenomena upon reduction of particles size, phonon modes, and phonon densities need to be carried out in a separate investigation as it proved to be a very interesting and important technological area [34].
3.3. Photoluminescence Emission. Figure 6(a) illustrated the room-temperature PL spectra (excitation at $325 \mathrm{~nm}$ ) of the samples deposited on $\mathrm{Si}$ at 200,300 , and $400^{\circ} \mathrm{C}$, Figure 6(b) on sample deposited on Si/Au and Figure 6(c) on sample deposited on $\mathrm{Si} / \mathrm{Au} / \mathrm{ZnO}$. Two emission bands could be observed from these samples, that is, (i) near band edge emission (at ultraviolet (UV) range) due to freeexciton recombination and (ii) visible emission, a deeplevel-emission (DLE) mostly in yellow-orange region was a consequence of presence of structural defect and impurities on the surface of samples [35-37]. Visible peaks at yelloworange emission band around $580 \mathrm{~nm}$ were generally emitted 


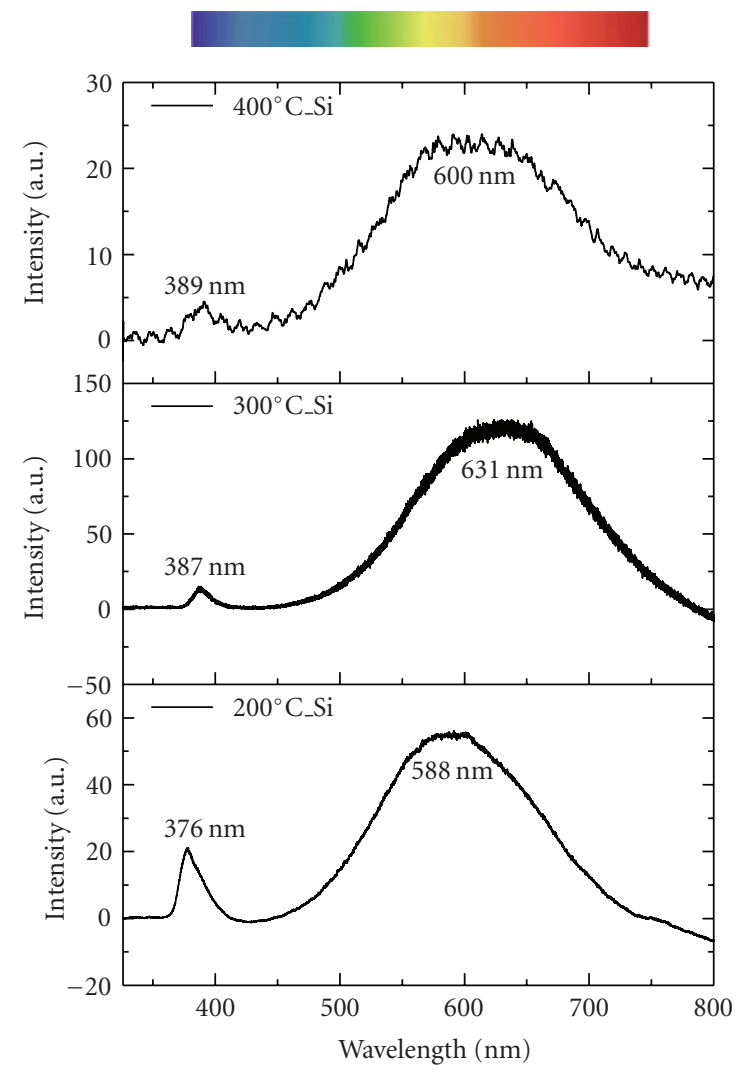

(a)

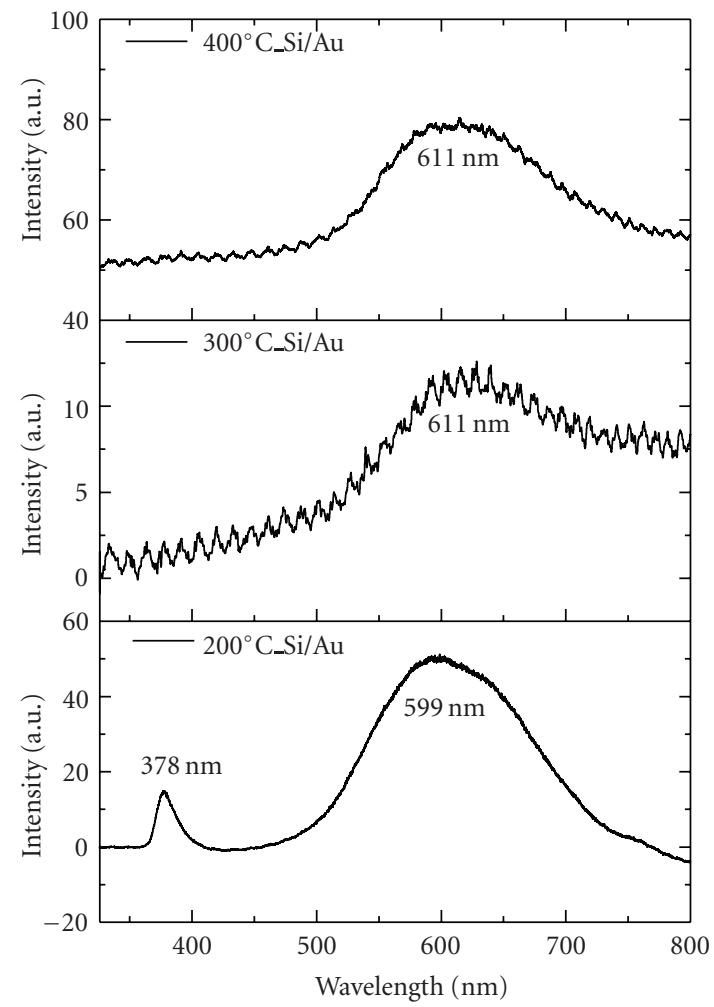

(b)

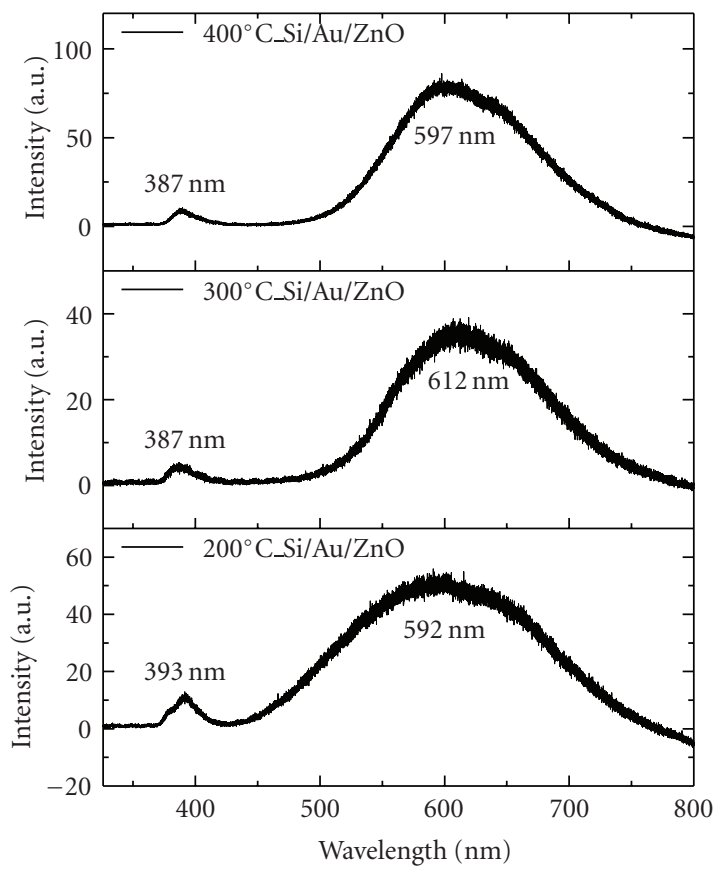

(c)

Figure 6: PL spectra of $\mathrm{ZnO}$ nanocrystalline thin film prepared by mist-atomisation technique on substrate (a) Si, (b) Si/Au, and (c) $\mathrm{Si} / \mathrm{Au} / \mathrm{ZnO}$ at 200,300 , and $400^{\circ} \mathrm{C}$. 


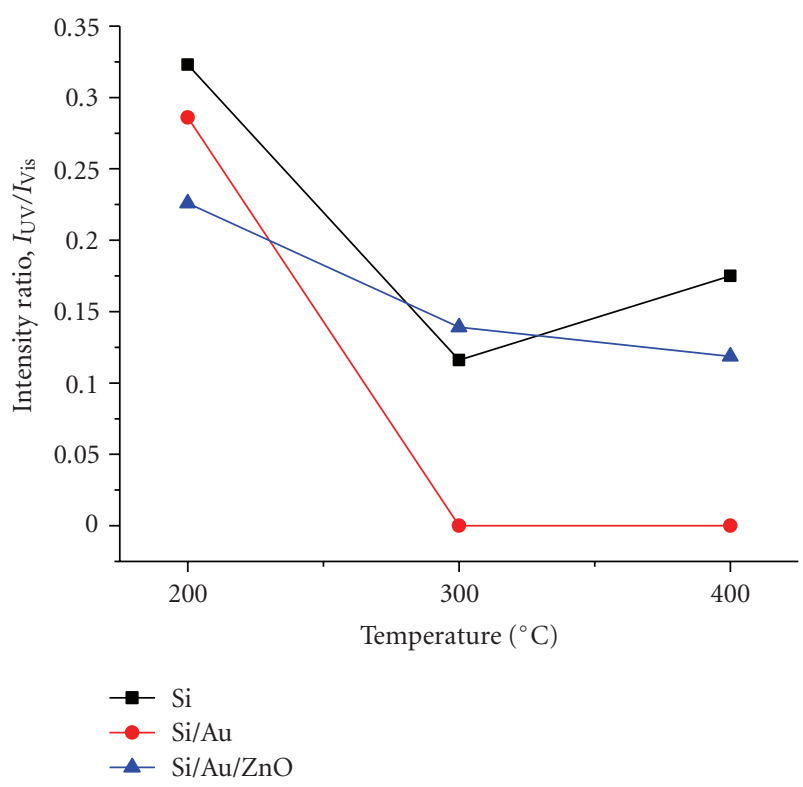

FIgURe 7: Intensity ratio of UV to visible emission $\left(I_{\mathrm{UV}} / I_{\mathrm{Vis}}\right)$ at various substrates' temperature and on various types of Si substrate surfaces.

by all samples. This band is common among solution-based grown $\mathrm{ZnO}$, and has been considered to be due to oxygen interstitial $\left(\mathrm{O}_{i}\right)$ related defects [38], that is, excess oxygen and presence of hydroxyl group and is related to the amount of exposed polar surface of $\mathrm{Zn}$ - and O-atom [39].

The UV emission of $\mathrm{ZnO}$ nanostructures deposited on $\mathrm{Si}$ and $\mathrm{Si} / \mathrm{Au}$ substrate on dissimilar temperatures showed a red-shift, that is, to a lower energy when the substrates' temperature changed from 200 to $400^{\circ} \mathrm{C}$. The result was consistent with the XRD, SEM findings, which revealed that the grain size were smallest at $200^{\circ} \mathrm{C}$ and expanded when the temperature of substrate increased [23, 40, 41]. The UV emission peaks of $\mathrm{ZnO}$ deposited on $\mathrm{Si} / \mathrm{Au} / \mathrm{ZnO}$ blue-shifted with increased substrates' temperature, showing coherent findings that as size decreases UV emission moved to higher energy level. An almost negligible UV emission can be seen for sample deposited on Si/Au substrates at 300 and $400^{\circ} \mathrm{C}$ which some attribute to excess $-\mathrm{OH}$ group that is responsible for quenching of the exciton emission [39]. The $-\mathrm{OH}$ group may have originated from solvent trapped in empty octahedral site in the hexagonal lattice structure of $\mathrm{ZnO}$.

The ratio of the intensities of UV to visible emission $\left(I_{\mathrm{UV}} / I_{\mathrm{Vis}}\right)$ as a function of substrate's temperature (Figure 7 ) was also analysed. It can be seen that prominent ratios are found on $T_{s}=200^{\circ} \mathrm{C}$ for all samples while bare Si surface has higher $I_{\mathrm{UV}} / I_{\mathrm{Vis}}$ ratio relative to $\mathrm{Si} / \mathrm{Au}$ and $\mathrm{Si} / \mathrm{Au} / \mathrm{ZnO}$.

\section{Conclusion}

Mist-atomiser has been successfully developed to prepare $\mathrm{ZnO}$ nanoparticles. This technique is economical, simple, and practical for mass-production purposes of $\mathrm{ZnO}$ thin films. Effects of Si substrates' surface type and substrates temperature, on the structural, morphological, and photoluminescence emission of $\mathrm{ZnO}$ nanoparticles have been investigated. X-ray diffraction patterns confirmed that all samples showed that polycrystalline nature corresponds to $\mathrm{ZnO}$ wurtzite structure. It was found that crystallite size and lattice strain were significantly affected by substrate surface type and temperature. Smallest crystallite size was found on $\mathrm{Si} / \mathrm{Au} / \mathrm{ZnO}$ at $T_{s}=400^{\circ} \mathrm{C}$, gold layer on substrate revealed no lattice strain at all deposition temperatures and at $T_{s}=400^{\circ} \mathrm{C}$ there was negligible strain on all substrates. PL emission study was in agreement with the expansion of crystallite size study. The chemical reaction that took place has been suggested as well as explanation for growth outcome. Both substrate surface type and deposition temperature has been found to significantly affect crystalline structure of $\mathrm{ZnO}$ nanoparticles.

\section{Acknowledgments}

The author would like to thank Universiti Teknologi MARA (UiTM) and Jabatan Perkhidmatan Awam (JPA) Malaysia for the financial support. The author also thanks Microwave Technology Centre (MTC), Faculty of Electrical Engineering, Faculty of Mechanical engineering and Faculty of Applied Sciences for SEM and XRD facilities.

\section{References}

[1] T. Terasako, M. Yagi, M. Ishizaki, Y. Senda, H. Matsuura, and S. Shirakata, "Growth of zinc oxide films and nanowires by atmospheric-pressure chemical vapor deposition using zinc powder and water as source materials," Surface and Coatings Technology, vol. 201, no. 22-23, pp. 8924-8930, 2007.

[2] M. H. Mamat, Z. Khusaimi, M. Z. Musa, M. Z. Sahdan, and M. Rusop, "Novel synthesis of aligned Zinc oxide nanorods on a glass substrate by sonicated sol-gel immersion," Materials Letters, vol. 64, no. 10, pp. 1211-1214, 2010.

[3] J. G. Lu, P. Chang, and Z. Fan, "Quasi-one-dimensional metal oxide materials — synthesis, properties and applications," Materials Science and Engineering R, vol. 52, pp. 49-91, 2006.

[4] X. Liu, X. Wu, H. Cao, and R. P. H. Chang, "Growth mechanism and properties of $\mathrm{ZnO}$ nanorods synthesized by plasma-enhanced chemical vapor deposition," Journal of Applied Physics, vol. 95, no. 6, pp. 3141-3147, 2004.

[5] M. Salavati-Niasari, F. Davar, and M. Mazaheri, "Preparation of $\mathrm{ZnO}$ nanoparticles from [bis(acetylacetonato)zinc(II)]oleylamine complex by thermal decomposition," Materials Letters, vol. 62, no. 12-13, pp. 1890-1892, 2008.

[6] M. Rusop, K. Uma, T. Soga, and T. Jimbo, "Post-growth annealing of zinc oxide thin films pulsed laser deposited under enhanced oxygen pressure on quartz and silicon substrates," Materials Science and Engineering B, vol. 127, no. 2-3, pp. 150153, 2006.

[7] E. T. Y. Lee, Y. Shimotsuma, M. Sakakura, M. Nishi, K. Miura, and K. Hirao, "Photo-initiated growth of zinc oxide $(\mathrm{ZnO})$ nanorods," Materials Letters, vol. 62, no. 24, pp. 4044-4046, 2008. 
[8] G. J. Fang, D. Li, and B.-L. Yao, "Influence of postdeposition annealing on the properties of transparent conductive nanocrystalline ZAO thin films prepared by RF magnetron sputtering with highly conductive ceramic target," Thin Solid Films, vol. 418, no. 2, pp. 156-162, 2002.

[9] M.-G. Ma, Y.-J. Zhu, G.-F. Cheng, and Y.-H. Huang, "Microwave synthesis and characterization of $\mathrm{ZnO}$ with various morphologies," Materials Letters, vol. 62, no. 3, pp. 507-510, 2008.

[10] Y. Du, C. Hao, and G. Wang, "Preparation of floral-patterned $\mathrm{ZnO} / \mathrm{MWCNT}$ heterogeneity structure using microwave irradiation heating method," Materials Letters, vol. 62, no. 1, pp. 30-32, 2008.

[11] J. H. Yang, J. H. Zheng, H. J. Zhai, and L. L. Yang, "Low temperature hydrothermal growth and optical properties of ZnO nanorods," Crystal Research and Technology, vol. 44, no. 1, pp. 87-91, 2009.

[12] M. S. Ghamsari and M. Vafaee, "Sol-gel derived zinc oxide buffer layer for use in random laser media," Materials Letters, vol. 62, no. 12-13, pp. 1754-1756, 2008.

[13] Z. Khusaimi, S. Amizam, H. A. Rafaie et al., "Photoluminescence and structural properties of gold-assisted zinc oxide nanorods," The Malaysian Journal of Science, vol. 28, pp. 197201, 2009.

[14] A. Mosbah, A. Moustaghfir, S. Abed et al., "Comparison of the structural and optical properties of zinc oxide thin films deposited by d.c. and r.f. sputtering and spray pyrolysis," Surface and Coatings Technology, vol. 200, pp. 293-296, 2005.

[15] P. S. Patil, "Versatility of chemical spray pyrolysis technique," Materials Chemistry and Physics, vol. 59, no. 3, pp. 185-198, 1999.

[16] J. B. Mooney and S. B. Radding, "Spray pyrolysis processing," Annual Review of Materials Science, vol. 12, pp. 81-101, 1982.

[17] K. Okuyama and I. W. Lenggoro, "Preparation of nanoparticles via spray route," Chemical Engineering Science, vol. 58, pp. 537-547, 2003.

[18] Z. Khusaimi, S. Amizam, M. H. Mamat et al., "Controlled growth of zinc oxide nanorods by aqueous-solution method," Synthesis and Reactivity in Inorganic, Metal-Organic and NanoMetal Chemistry, vol. 40, no. 3, pp. 190-194, 2010.

[19] P. Singh, A. Kumar, Deepak, and D. Kaur, "Growth and characterization of $\mathrm{ZnO}$ nanocrystalline thin films and nanopowder via low-cost ultrasonic spray pyrolysis," Journal of Crystal Growth, vol. 306, no. 2, pp. 303-310, 2007.

[20] J. Prywer, "Kinetic and geometric determination of the growth morphology of bulk crystals: recent developments," Progress in Crystal Growth and Characterization of Materials, vol. 50, pp. 1-38, 2005.

[21] S.-Y. Pung, K.-L. Choy, and X. Hou, "Tip-growth mode and base-growth mode of Au-catalyzed zinc oxide nanowires using chemical vapor deposition technique," Journal of Crystal Growth, vol. 312, no. 14, pp. 2049-2055, 2010.

[22] B. Joseph, K. G. Gopchandran, P. V. Thomas, P. Koshy, and V. K. Vaidyan, "A study on the chemical spray deposition of zinc oxide thin films and their structural and electrical properties," Materials Chemistry and Physics, vol. 58, no. 1, pp. 71-77, 1999.

[23] M. Ghosh and A. K. Raychaudhuri, "Shape transition in $\mathrm{ZnO}$ nanostructures and its effect on blue-green photoluminescence," Nanotechnology, vol. 19, no. 44, Article ID 445704, 2008.
[24] V. Ramaswamy, P. Awati, and A. K. Tyagi, "Lattice thermal expansion of LaCo1-xCuxO3," Journal of Alloys and Compounds, vol. 364, no. 1-2, pp. 180-185, 2004.

[25] A. Ashour, "Physical properties of spray pyrolysed CdS thin films," The Turkish Journal of Physics, vol. 27, no. 6, pp. 551558, 2003.

[26] P. Singh, A. Kumar, Deepak, and D. Kaur, "ZnO nanocrystalline powder synthesized by ultrasonic mist-chemical vapour deposition," Journal of Crystal Growth, vol. 306, pp. 303-310, 2008.

[27] Y. J. Li, R. Duan, P. B. Shi, and G. G. Qin, "Synthesis of ZnO nanoparticles on Si substrates using a ZnS source," Journal of Crystal Growth, vol. 260, no. 3-4, pp. 309-315, 2004.

[28] R. Maity, S. Das, M. K. Mitra, and K. K. Chattopadhyay, "Synthesis and characterization of $\mathrm{ZnO}$ nano/microfibers thin films by catalyst free solution route," Physica E, vol. 25, no. 4, pp. 605-612, 2005.

[29] Y. Takakuwa, F. Ishida, and T. Kawawa, "Time evolution of interface roughness during thermal oxidation on $\operatorname{Si}\left(\begin{array}{lll}0 & 0 & 1\end{array}\right)$," Applied Surface Science, vol. 190, pp. 20-25, 2002.

[30] A. Omura, H. Sekikawa, and T. Hattori, "Lateral size of atomically flat oxidized region on Si(111) surface," Applied Surface Science, vol. 117-118, pp. 127-130, 1997.

[31] B. Feng, Z. Li, and X. Zhang, "Prediction of size effect on thermal conductivity of nanoscale metallic films," Thin Solid Films, vol. 517, no. 8, pp. 2803-2807, 2009.

[32] K. Kakimoto, A. Murakawa, and Y. Hashimoto, "An investigation of thermal conductivity of isotope silicon as a function of temperature estimated by molecular dynamics," Journal of Crystal Growth, vol. 275, no. 1-2, pp. e427-e432, 2005.

[33] C. M. Barrado, E. R. Leite, P. R. Bueno, E. Longo, and J. A. Varela, "Thermal conductivity features of ZnO-based varistors using the laser-pulse method," Materials Science and Engineering A, vol. 371, no. 1-2, pp. 377-381, 2004.

[34] Z. L. Wang, "Zinc oxide nanostructures: growth, properties and applications," Journal of Physics Condensed Matter, vol. 16, no. 25, pp. R829-R858, 2004.

[35] L. Schmidt-Mende and J. L. MacManus-Driscoll, " $\mathrm{ZnO}-$ nanostructures, defects, and devices," Materials Today, vol. 10, no. 5 , pp. 40-48, 2007.

[36] C. Chandrinou, N. Boukos, C. Stogios, and A. Travlos, "PL study of oxygen defect formation in $\mathrm{ZnO}$ nanorods," Microelectronics Journal, vol. 40, no. 2, pp. 296-298, 2009.

[37] Y. Sun, N. G. Ndifor-Angwafor, D. J. Riley, and M. N. R. Ashfold, "Synthesis and photoluminescence of ultra-thin $\mathrm{ZnO}$ nanowire/nanotube arrays formed by hydrothermal growth," Chemical Physics Letters, vol. 431, pp. 352-357, 2006.

[38] S. S. Kurbanov, G. N. Panin, T. W. Kim, and T. W. Kang, "Strong violet luminescence from $\mathrm{ZnO}$ nanocrystals grown by the low-temperature chemical solution deposition," Journal of Luminescence, vol. 129, no. 9, pp. 1099-1104, 2009.

[39] A. B. Djuriić, A. M. C. Ng, and X. Y. Chen, "ZnO nanostructures for optoelectronics: material properties and device applications," Progress in Quantum Electronics, vol. 34, no. 4, pp. 191-259, 2010.

[40] J. Yang, M. Gao, Y. Zhang et al., "Effects of annealing temperature on morphologies and optical properties of $\mathrm{ZnO}$ nanostructures," Superlattices and Microstructures, vol. 44, no. 2, pp. 137-142, 2008.

[41] G. N. Karanikolos, P. Alexandridis, G. Itskos, A. Petrou, and T. J. Mountziaris, "Synthesis and size control of luminescent ZnSe nanocrystals by a microemulsion-gas contacting technique," Langmuir, vol. 20, no. 3, pp. 550-553, 2004. 

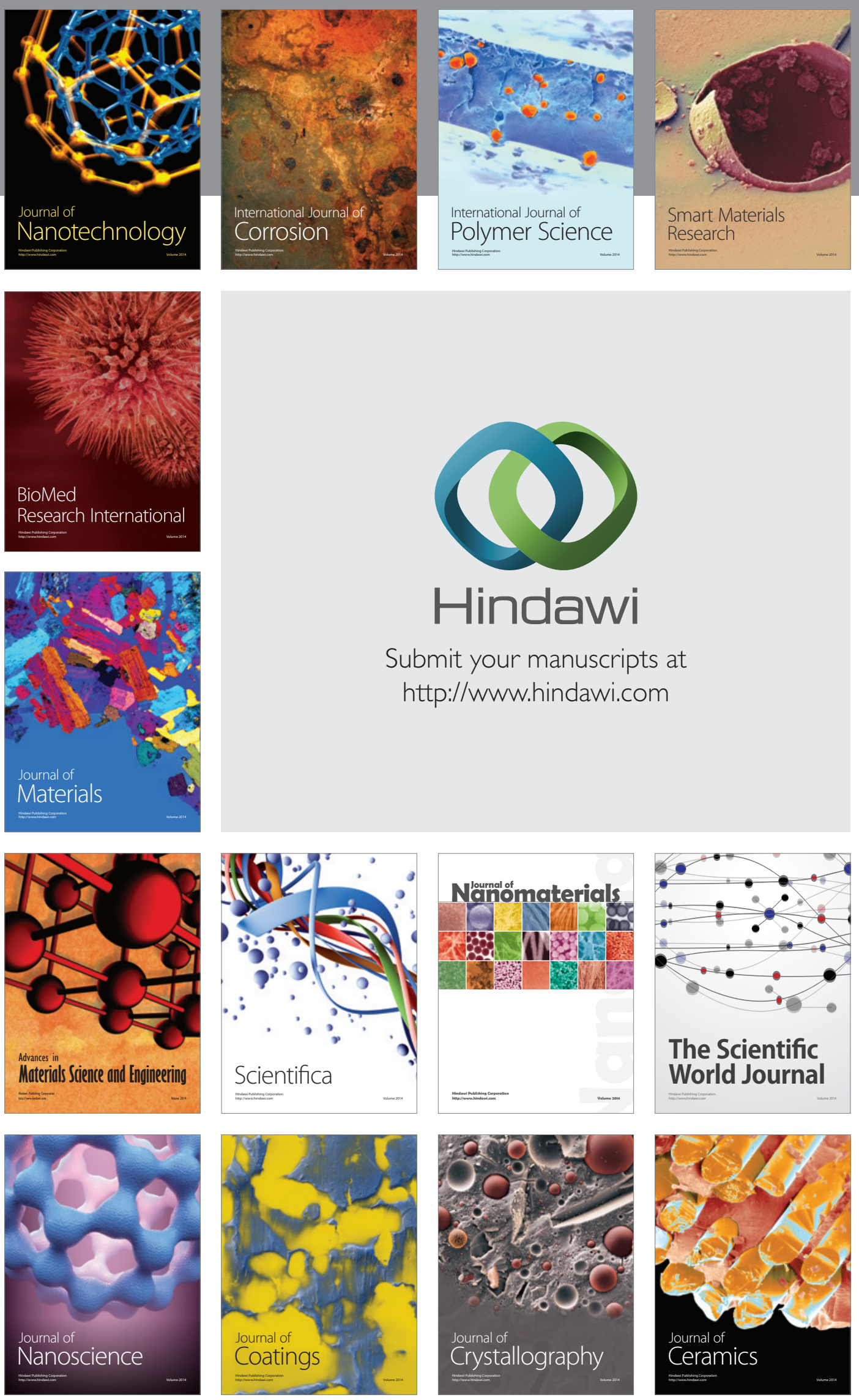

The Scientific World Journal

Submit your manuscripts at

http://www.hindawi.com

\section{World Journal}

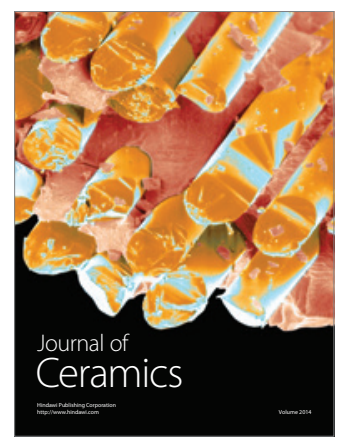

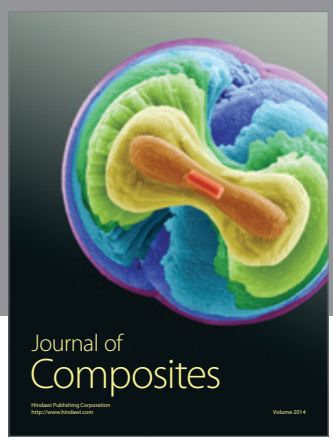
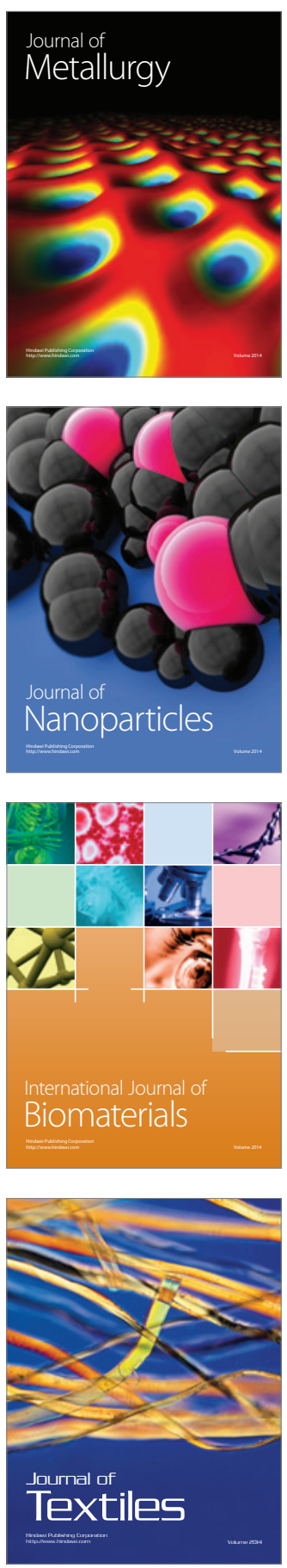